\title{
The Juridical Overview Of Customary Land Registration
}

\author{
Intan Haryanti*) Umar Ma'ruf*), and Rakhmat Bowo**) \\ *) State Civil Apparatus (ASN) at Regional Secretariat of Grobogan Regency, E-mail \\ intanharyanti16@gmail.com \\ ${ }^{* *}$ Faculty of Law, Universitas Islam Sultan Agung Semarang \\ ${ }^{* * *}$ Faculty of Law, Universitas Islam Sultan Agung Semarang
}

\begin{abstract}
Indonesia in Article 18 B paragraph 2 states that the State recognizes and respects customary law community units and their traditional rights as long as they are still alive and in accordance with community development and the principles of the Unitary State of the Republic of Indonesia, which are regulated by law. This study aims to 1). Describe the Land Registration Policy in the current era; 2). Describe the legal policy of ulayat land registration. This type of research is a doctrinal research with a juridical approach that uses secondary data as the main data source. The current land registration policy is based on the Regulation of the Minister of Agrarian Affairs and Spatial Planning/Head of the National Land Agency of the Republic of Indonesia Number 6 of 2018 concerning Complete Systematic Land Registration (PTSL) which targets 126 million parcels of certified land throughout Indonesia by 2025. Policy on ulayat land registration Referring to PP No. 27 of 1999 concerning registration, it does not make ulayat land as land that can be issued a certificate, even though providing legal guarantees and protection for ulayat land is a mandate of the 1945 Constitution of the Republic of Indonesia and the UUPA. Therefore, the government can issue a Certificate of Customary Land through a Regional Regulation as the output of the Customary Land Registration.

Keywords: Law; Land Registration; Customary Land Rights.
\end{abstract}

\section{Introduction}

Indonesia has a cultural pluralist character. This condition is seen in the many ethnicities, tribes, religions, customs and others that enrich Indonesian culture. Each tribe has a different language, values and works. The reality of Indonesia which is diverse in culture is in line with Hefner's opinion that Indonesia is plural-cultural. ${ }^{1}$ This cultural diversity forms the face of law in each different tribe, religion and ethnicity. Laws that are born from the womb of cultural diversity are laws that grow and develop from society itself which Von Savigny calls Volkgeist (the soul of the nation). Indonesia in its land law system rests on the LoGA which is the law on land. In terms of land ownership, the LoGA emphasizes more on the aspect of individual land ownership ${ }^{2}$ and does not emphasize customary land ownership so that the position of customary land ownership of indigenous peoples is still very weak because it is still declarative in nature with restrictions: (a) as long as it is still alive, (b) in accordance with

\footnotetext{
${ }^{1}$ Hefner, R. W. (2011). Civil islam: Muslims and democratization in indonesia (Vol. 40). Princeton University Press, p. 4.

${ }^{2}$ Arie S. Hutagalung in Haris, A. 2005, Pengaruh Penatagunaan Tanah terhadap Keberhasilan Pembangunan Infrastruktur dan Ekonomi, Perencanaan Pembangunan, p. 5.
} 
community development, and (c) in accordance with the principles of -principles of the Unitary State of the Republic of Indonesia. ${ }^{3}$ The existence of customary law community units has not received fair protection from the state so that the nature of state recognition is only pseudo-recognition. ${ }^{4}$ Consequently, customary law communities remain in a marginalized position politically, economically, socially and culturally. In fact, several studies have proven that until the end of the 20th century, in Indonesia there are still many scattered lands, including forests whose control is based on traditional rules (customary law), even though the "modern" legal rules governing this land have existed since the colonial era. (1870). However, until now there is no complete information about the landscape and boundaries of the areas covered by these various customary laws. So it is necessary to synchronize customary law with the written law of the State of Indonesia, so that there is no overlap between customary law and other written laws. ${ }^{5}$ Bearing in mind, these ulayat areas are usually in a strategic position within the customary law community. It is related to economic, social, cultural, and political elements that are formed based on historical, legal, administrative, and functional developments. ${ }^{6}$

Observing the development of land issues in the 60 years since the promulgation of Act No. 5 of 1960, the facts about the occurrence of conflicts are caused by the government's lack of professionalism in arranging legal norms, causing conflicts in the management of natural resources in several areas in Indonesia. ${ }^{7}$ The land issue has become a cross-sectoral problem involving all aspects of life. In this context, land is multidimensional, namely physical, chemical, biological, social, economic, political and religious dimensions, each of which has the potential to provide welfare for human beings. ${ }^{8}$ This potential does not necessarily run well, because it is prone to land conflicts. In general, the motives and backgrounds for the emergence of various land conflicts include (1) the lack of order in land administration in the past, (2) the condition of the community being increasingly aware and understanding of their interests and rights, (3) a climate of openness as one of the policies outlined by the government. , (4) there are still many lands that do not have certificates, (5) land that is controlled by someone does not necessarily belong to the person who occupies it, (6) the process of inheritance of land is not determined through legal mechanisms, (7) there is still land that is communal control which at any time can lead to conflict, ${ }^{9}$ As an effort to minimize land conflicts, especially for customary

\footnotetext{
${ }^{3}$ Article 3 of the Basic Agrarian Act No. 5 of 1960.

${ }^{4}$ Nurjaya, I. N. (2011). Adat Community Lands Right as Defined within the State Agrarian Law of Indonesia: Is It a Genuine or Pseudo-Legal Recognition. US-China Law Review, 8, p. 385

${ }^{5}$ Ismi, H. (2012). Pengakuan dan perlindungan hukum hak masyarakat adat atas tanah ulayat dalam upaya pembaharuan hukum nasional. Jurnal Ilmu Hukum, 3 (1). p. 7.

${ }^{6}$ Adonia I. Laturette. Kewenangan Pemerintah Daerah Terhadap Tanah ulayat. Jurnal Sasi Vol. 17 No. 3 July-September 2011, p. 7

${ }^{7}$ Husen, A. (2011). Dinamika Hukum Dalam Pengakuan dan Perlindungan Hak Masyarakat Hukum Adat Atas Tanah. Yogyakarta: LaksBang Pressindo. p. 7

${ }^{8}$ Muljono, B. E. (2016). Pendaftaran Tanah Pertama Kali Secara Sporadik Melalui Pengakuan Hak. Jurnal Independent, 4(1), 20-27. p. 21

${ }^{9}$ Chomzah in Windari, R. A. (2014). Keberpihakan Regulasi Pertanahan terhadap Hak Masyarakat Adat (Studi Kasus Sengketa Tanah Adat di Desa Kubutambahan, Kecamatan Kubutambahan,
} 
land rights, it is necessary to have good faith from the government to provide legal guarantees and protection for these customary lands through the mechanism or policy currently being rolled out, namely the Regulation of the Minister of Agrarian Affairs and Spatial Planning/Head of the National Land Agency of the Republic of Indonesia Number 6 of 2018 concerning Complete Systematic Land Registration (PTSL). This is to anticipate the tendency of rulers and entrepreneurs to deny the rights of customary law communities, which objectively have a weaker position than those of entrepreneurs and rulers who have stronger economic, social and political positions. ${ }^{10}$ The presence of policies has an important position by paying attention to the stages of policy formulation, starting from problem formulation which is the stage to recognize and formulate problems as the most fundamental step in policy formulation. ${ }^{11}$ that empowers and is carried out not only focused individually but also collectively and all of that must be part of the actualization and co-actualization of human existence and humanity. ${ }^{12}$

In relation to land registration, ulayat land is not a right that can be registered if it refers to Article 9 of Regulation - Government Number 24 of 1997 concerning Land Registration which explains that the objects of Land Registration include: 1). Plots of land that are owned with property rights, cultivation rights, building rights and use rights; 2). Land management rights; 3). waqf land; 4). Ownership rights to the apartment unit; 5). Mortgage right; 6) State Land.

According to this Government Regulation No. 24 of 1997, ulayat rights cannot be registered because ulayat rights are not included in the object of land registration, Article 3 states that "To provide legal certainty and legal protection to holders of rights to a plot of land, apartment units and registered rights, so that they can easily prove themselves as holders of the rights concerned. For this reason, the right holder is given a certificate as proof.

In fact, the guarantee of legal certainty in the land sector to the community with written, complete and clear legal instruments that are implemented consistently is needed to provide legal certainty in the agrarian sector, including ulayat land. In this case, what is no less important is the implementation of legal certainty for indigenous peoples who own land so that there is a guarantee of legal certainty over the rights to the land. Based on this phenomenon, the researchers then tried to adopt in this study to review the legal registration of land for customary land rights.

\section{Research Methods}

The approach used is a juridical approach that uses secondary data as the

Kabupaten Buleleng). Jurnal Ilmu Sosial dan Humaniora, 3(1), p. 329.

10Ismail, I. (2010). Kedudukan dan Pengakuan Hak Ulayat Dalam Sistem Hukum Agraria Nasional. Kanun Jurnal Ilmu Hukum, 12 (1), p. 57.

${ }^{11}$ Nurhayati, N., \& Bangsawan, M. I. (2019). The Sustainable Development Licensing Policy Of Creative Industry In The Era of Asean Economic Community (AEC) In Surakarta, Indonesia. Humanities \& Social Sciences Reviews, 7 (3), p. 29.

${ }^{12}$ Bangsawan, M. I. (2017). Pemberdayaan Ekonomi Kreatif di Kota Surakarta Melalui Instrumen Hukum Perizinan Industri Kreatif. Perizinan di Era Citizen Friendly, p. 321. 
main data source. The method of data collection was carried out by standard research methods, namely by literature studies in accordance with research problems by taking an inventory of various main and supporting library materials related to the focus of the problem with the aim of obtaining a general and relatively comprehensive picture of what was included in the focus of the current problem. researched.

\section{Results and Discussion}

\subsection{Land Registration Legal Policy}

Land in human life has a very important role because land is a source of prosperity, prosperity, and life. In addition, land has a close relationship with humans because land has economic value for human life and can produce natural resources for many people. ${ }^{13}$ The existence of land is increasingly important in connection with the increasing population growth and rapid development activities which cause the need for land to increase while on the other hand the land supply is relatively very limited. ${ }^{14}$ On land, rights are granted which authorize the holder of the rights (either individually, groups of people together or legal entities) to use in the sense of controlling, using and or taking advantage of certain plots of land. ${ }^{15}$ The mandate of Article 19 paragraph (3) of the UUPA states that land registration is carried out keeping in mind the state and community conditions, the needs of socio-economic traffic and the possibility of its implementation according to the consideration of the Minister of Agrarian Affairs. ${ }^{16}$ In addition to land registration, it is also necessary to have an even distribution of land resources, production factors and a balanced (fair) economy so as to realize the welfare of all levels of society within the framework of sustainable development. ${ }^{17}$ The current land policy rolled out by the government departs from dissatisfaction with land registration that has been registered in Indonesia. This is as stated in PP No. 10 of 1961 concerning land registration for the first time and has been in effect for more than 35 years, shows data that approximately 16.3 million parcels have been registered from around 55 million parcels of private land. Likewise with the enactment of PP No. 24 of 1997 refinement of PP No. 10 of 1961, the implementation of land registration has not been maximized, of 126 million land parcels in Indonesia, only 46 million have been registered, this means that there are 80 million land parcels that have not

\footnotetext{
${ }^{13}$ Setyani, A. N., \& Suwondo, D. (2020). Tinjauan Yuridis Peralihan Hak Atas Tanah Karena Jual Beli Di Kabupaten Demak. Prosiding Konferensi Ilmiah Mahasiswa Unissula (KIMU) Klaster Hukum, p. 325.

${ }^{14}$ Abe, R. S., \& Witasari, A. (2020). Tinjauan Hukum Terhadap Prosedur Pengukuran Ulang Tanah Sebagai Penyelesaian Sengketa Batas Kepemilikan Tanah Di Kantor Pertanahan Kabupaten Blora. Prosiding Konferensi Ilmiah Mahasiswa Unissula (KIMU) Klaster Hukum, p. 49.

${ }^{15}$ Suwondo, D., \& Saputra, I. (2019). Peran Dan Tanggung Jawab Pejabat Pembuat Akta Tanah Dalam Pelaksanaan Kegiatan Pendaftaran Tanah. Jurnal Hukum, 35 (2), p. 185.

16Santoso Urip. (2012). Hukum Agraria Kajian Komprehensif, Jakarta: Kencana Prenada Media Group, p. 296.

${ }^{17}$ Absori, A. (2006). Deklarasi Pembangunan Berkelanjutan dan Implikasinya di Indonesia, Jurnal Ilmu Hukum, Vol. 9, No. 1, p. 42.
} 
been registered. Meanwhile, according to Van Der Eng in Wahyuni explained that the growth of land parcels is more than 1 million parcels per year. ${ }^{18}$

President Joko Widodo in his first term of office had good intentions to realize agrarian reform through one of the nine priority agendas (Nawacita) which was the implementation of Jokowi-JK which pushed for 9 million hectares of land reform and land ownership programs. ${ }^{19}$ However, this good will must be tested first so that it does not become mere nonsense, especially to anticipate Indonesia's sovereignty over the dictation policies of developed countries which are characterized by global capitalism. ${ }^{20}$ This means that the efforts of capitalist countries to use their influence in Indonesia to initiate a new style of colonialism (neo-colonialism) have entered an "extraordinary" level. ${ }^{21}$ Especially facing land problems, including the still strong sectoralization and contestation of control over state lands which are divided into three major sectors, namely the mining, plantation and forestry sectors. ${ }^{22}$

Table 1.1 Land tenure by various sectors in Indonesia

\begin{tabular}{lll}
\hline Land Area of Indonesia & Millions of Hectares & $100 \%$ \\
\hline $\begin{array}{l}\text { Forest area } \\
\text { (forest reserve 31.5 million hectares) }\end{array}$ & 137,45 & $79,45 \%$ \\
\hline Mining area & 2,15 & $1,25 \%$ \\
\hline Plantation area & 20 & $11,56 \%$ \\
\hline $\begin{array}{l}\text { Time (for farmers?), has not been } \\
\text { reduced residential Area, industrial } \\
\text { and tourism area. }\end{array}$ & 13,40 & $7,74 \%$ \\
\hline Total & 173 & $100 \%$ \\
\hline
\end{tabular}

Source: Anonymous, 2010. Ministry of Energy and Mineral Resources, Directorate General of Mineral and Coal

The current land registration policy refers to Ministerial Regulation Number 6 of 2018 concerning Complete Systematic Land Registration in which the ministry of ATR/BPN targets 126 million parcels of certified land throughout Indonesia by $2025 .^{23}$ Land registration through the agrarian reform agenda in the era of President Jokowi provides easy access for farmers/poor communities to be

\footnotetext{
18Mujiburohman, D.A., (2018). Potensi Permasalahan Pendaftaran Tanah Sistematik Lengkap (PTSL), BHUMI: Jurnal Agraria dan Pertanahan, 4 (1), p. 88

19 Santosa, S., Wicaksono, A., \& Nugroho, R. (2019). Multi-Role Collaboration of Ministries and Institutions in the Implementation of Agrarian Reform in Indonesia. BHUMI: Jurnal Agraria dan Pertanahan, 5 (3), p. 9

${ }^{20}$ Kodir, A., \& Mushoffa, I. (2017). Islam, Agrarian Struggle, and Natural Resources: The Exertion of Front Nahdliyin for Sovereignty of Natural Resources Struggle Towards Socio-Ecological Crisis in Indonesia. KARSA: Journal of Social and Islamic Culture, 25 (1), p. 79.

${ }^{21}$ Andreas, R., Adi, L. K., \& Sulastuti, S. (2019). The Effect of Colonialism on Implementation of Agrarian Reform in Indonesia. Fiat Justisia: Jurnal Ilmu Hukum, 13 (2), p. 109.

${ }^{22}$ Bangsawan, M., \& Absori, S. H. (2019). Kebijakan sertifikasi tanah dan implikasinya terhadap kesejahteraan masyarakat (Doctoral dissertation, Universitas Muhammadiyah Surakarta).

${ }^{23}$ Mujiburohman, D.A., (2018), Potensi Permasalahan Pendaftaran Tanah Sistematik Lengkap (PTSL), BHUMI: Jurnal Agraria dan Pertanahan, 4(1), p. 89.
} 
involved in land market schemes. ${ }^{24}$ Based on this, agrarian policy is very important because economically, land is very different from other production factors, such as fertilizer, labor, seeds, etc., which can be reproduced. Land, on the other hand, is a fixed factor of production. It also represents capital in the form of assets or investments, which is an indicator of well-being. ${ }^{25}$ The stability and sustainability of President Jokowi's administration needs to be managed optimally and adequately prepare for the better implementation of Nawacita II for post 2019-2024 so that it can support the interests of the people to achieve the ideals of the Indonesian Revolution of Independence. ${ }^{26}$

\subsection{Legal Policy for Land Registration of Customary Rights}

Land registration is something important as a proof of rights that are considered strong against land rights to prove legal ownership of land rights, besides that land registration which has been determined in article 19 of the BAL aims to make legal simplicity, so all good land that is owned in the name of a person, group or legal entity, both customary property rights or land rights according to book II of the Civil Code are required to be converted to one of the land rights that have been determined by the UUPA and registered for the realization of legal certainty and simplicity in land law. ${ }^{27}$

Indonesia in accordance with the objectives of the Indonesian LoGA in the laws and regulations on natural resources products of the State, has set the conditions for the recognition and respect for Indigenous Law Communities. The most recent regulation is the second amendment to the 1945 Constitution of the Republic of Indonesia, specifically the provisions of Article 18 B Paragraph 2 that "The State recognizes and respects customary law community units and their traditional rights as long as they are still alive and in accordance with the development of society and the principles of the Unitary State of the Republic of Indonesia, which are regulated by law". The regulation regarding the Indigenous Law Community is placed as part of the regulation concerning the Regional Government. The term used in the Article is "Indigenous Law Community units". Before the term Customary Law Community was included in the Amendment to the 1945 Constitution of the Republic of Indonesia, various laws and regulations had already mentioned it. For example, in Act No. 5 of 1960 concerning Basic Agrarian Regulations, specifically Article 2 (4) which stipulates that "The above implementation rights of the State can be delegated to autonomous regions and customary law communities, only necessary and does not conflict with national interests, according to the provisions of Government Regulations". Then also in

24 Prasetyo, F. (2019). The struggle for land rights: Indonesian (Urban) Agrarian Reform and (Against) the Global Land Forum in Bandung. https://platypus1917. org/2019/07/02/the-strugglefor-land-rights/, p. 3.

25 Widodo, S. (2017). A Critical Review of Indonesia's Agrarian Reform Policy. Journal of Regional and City Planning, 28 (3), p. 205.

${ }^{26}$ Razuni, G., \& Pramanti, A. (2020). No Agrarian Reform: Revolutie Without Revolution? Jurnal Partisipatoris, 2 (1), p. 16.

${ }^{27}$ Markus, D. P., \& Purnawan, A. (2017). Analisis Yuridis Kedudukan Hukum Adat dan Peranan Notaris-ppat dalam Proses Pendaftaran Tanah Menurut Undang-undang Pokok Agraria di Kota Sorong Papua Barat. Jurnal Akta, 4(3). 
Act No. 41 of 1999 concerning Forestry, Article 4 Paragraph (3) which stipulates that "State control of forests shall continue to pay attention to the rights of customary law communities, as long as they exist and their existence is recognized. ${ }^{28}$

The consequences of state recognition of the existence of indigenous peoples in all aspects of their lives, including in the land aspect, are constitutional mandates and laws that must be protected. However, in reality until now there are still perceived injustices such as cases related to communal land due to administrative weaknesses stratification of land ownership status that is not certified by the community because it is considered legally owned as the right of indigenous peoples, such as the case of the seizure of customary land in Klungkung and Kintamani Bangli with the puri who claimed ownership of the land based on a certificate of ownership. ${ }^{29}$ In fact, the recognition of the customary lands of indigenous peoples can be known if their existence can still be found by the existence of traditional ceremonies that are still taking place, customary sanctions that are still being enforced, and their customary lands that still exist. The status of their own ulayat land is evidenced by the existence of a tombo or book containing their history, territorial boundaries and customary management, legally they do not have written evidence in the form of a certificate but the existing circumstances can be used to explain their ulayat land ownership status. $^{30}$ Not a few later phenomena such as the state's right to control egology, namely the practice of taking over community-owned land in the name of the public interest and or prioritizing state control rights often occur and even trigger land conflicts. ${ }^{31}$

The current condition of customary land in Indonesia is based on the customary land law, the status of ownership is unclear due to the absence of land registration and recognition of property rights. This is coupled with weak laws due to the absence of land ownership rights to prove ownership of land rights as regulated in the UUPA, which causes it to be easily transferred by various parties. ${ }^{32}$ Ownership of land rights is a basic and important thing in human life, therefore it is necessary to hold land registration to clarify the status of the land, in this case the ulayat land of the customary law community. In Act No. 5 of 1960 concerning Basic Agrarian Regulations (UUPA) it has been determined that lands throughout the territory of the Republic of Indonesia must be inventoried in such a way that they really help efforts to improve people's welfare in the context of realizing social justice.

\footnotetext{
28 Sabardi, L. (2014). Konstruksi Makna Yuridis Masyarakat Hukum Adat dalam Pasal 18B UUDN RI Tahun 1945 untuk Identifikasi Adanya Masyarakat Hukum Adat.Jurnal Hukum \& Pembangunan, 44(2), p. 171

29 Windari, R. A. (2014). Keberpihakan Regulasi Pertanahan terhadap Hak Masyarakat Adat (Studi Kasus Sengketa Tanah Adat di Desa Kubutambahan, Kecamatan Kubutambahan, Kabupaten Buleleng). Jurnal Ilmu Sosial dan Humaniora, 3(1). p. 330

30 Pratiwi, S. I. (2015). Penyelesaian Sengketa Tanah Ulayat Antara Masyarakat Hukum Adat Dengan Taman Nasional Tessonilo. Kumpulan Jurnal Mahasiswa Fakultas Hukum, p. 12

31Manoe, S. B. (2014). Konstruksi Hak Menguasai Negara Dalam Tata Laksana Pengadaan Tanah Bagi Kepentingan Umum Di Kabupaten Semarang. Jurnal Pembaharuan Hukum, 1(2), p. 228.

32 Murad in Rombot, D. A. E. (2015). Pendaftaran tanah adat dan pembangunan masyarakat Minahasa di Indonesia (Doctoral dissertation, Universiti Sains Malaysia), p. 4.
} 
The affirmation of the application of customary law can be seen in Article 5 of the UUPA which reads "Agrarian law applicable to earth, water and space is customary law, as long as it does not conflict with national and state interests, which is based on national unity, with Indonesian socialism and with regulations. - the regulations contained in this Law and with other laws and regulations, everything by taking into account the elements that rely on religious law". Even in the case of land registration,

The enactment of the Customary Land Regional Regulation (Perda) will have both positive and negative impacts. The positive impact is indicated by (strengthening) the recognition of various parties to SKTA as the basis for rights or initial evidence. This can be seen by observing four events, namely: 1). Land acquisition by way of compensation; 2). Borrow and use customary land; 3). Making a deed of transfer of land rights; and 4). Application for Cultivation Rights. In addition, the acknowledgment is based on the fact that the indigenous peoples carry out cultivation and utilization. Creating a legal relationship between the subject and the object, namely in the form of physical control over the land (utilization and cultivation), this is the main consideration in processing the application for rights. SKTA is a reinforcement for the physical mastery. ${ }^{33}$ This will at the same time legitimize the nature of ulayat land in which ulayat land rights have outward and inward characteristics. The inward nature means that it allows members of the customary law alliance to take advantage of the land and everything that grows and lives on it (managing the land, establishing residences, herding livestock, gathering food and hunting and fishing). This right is limited only to the interests of the family itself. The nature of exit means a prohibition against outsiders or foreigners to take advantage of the land unless there is prior permission from the customary heads and are required to pay recognition money or recognition money. ${ }^{34}$

The negative impact is indicated by the uncertainty of the status of land rights, the main cause of which is the emergence of multiple claims as described earlier, the granting of SKTA brings certainty of tenure rights for indigenous peoples. However, because the practice of granting SKTA has developed in such a way, the granting of SKTA actually creates uncertainty about the rights of other parties. Overlapping claims and recurring claims to land are the two main factors that cause this uncertainty. Overlapping of claims occurs if the control or ownership of one or several parcels of land is claimed by more than one person or party using the same or different types of base or proof of rights. Meanwhile, recurring claims are claims of ownership of land more than once by different people to be used as the basis for claiming compensation. Apart from overlapping and repeated claims, the uncertainty of rights can also occur due to the actions of the security functionaries who oblige through a circular letter for indigenous people in their territory to take care of SKTA without exception. ${ }^{35}$

\footnotetext{
33 Simarmata, R. (2015). Kedudukan Hukum dan Peluang Pengakuan Surat Keterangan Tanah Adat. Kemitraan bagi Pembaruan Tata Pemerintahan, p. 25

34 Yarsina, N. (2018). Perlindungan Hukum Terhadap Tanah Ulayat Yang Telah Bersertifikat Di Kota Bukittinggi. JCH (Jurnal Cendekia Hukum), 3 (2), p. 170

35Simarta, 2015. Ibid. p. 27
} 


\section{Closing}

The legal land registration policy rolled out by the government in the current era is based on the Regulation of the Minister of Agrarian Affairs and Spatial Planning/Head of the National Land Agency of the Republic of Indonesia Number 6 of 2018 concerning Complete Systematic Land Registration (PTSL) agrarian reform in order to reorganize unequal land tenure, ownership and use to create the bases of people's productive forces and realize social justice. The legal policy for registration of ulayat land rights when reviewed is Article 9 of Regulation - Government Number 24 of 1997 concerning Registration that ulayat land is not a right that can be registered if it refers to the said government regulation. However, as a form of providing guarantees and legal protection for ulayat land which is the mandate of the 1945 Constitution of the Republic of Indonesia and the UUPA. Then the government can issue a Certificate of Customary Land through a Regional Regulation as an output from the Customary Land Registration. Through the enactment of Regional Regulations concerning Customary Land Certificates, it will have positive and negative impacts at the same time. The positive impact is indicated by (strengthening) the recognition of various parties to SKTA as the basis for rights or initial evidence.

\section{References}

\section{Journal}

[1] Abe, R. S., \& Witasari, A. (2020). Tinjauan Hukum Terhadap Prosedur Pengukuran Ulang Tanah Sebagai Penyelesaian Sengketa Batas Kepemilikan Tanah Di Kantor Pertanahan Kabupaten Blora. Prosiding Konferensi Ilmiah Mahasiswa Unissula (KIMU) Klaster Hukum.

[2] Absori, A. (2006). Deklarasi Pembangunan Berkelanjutan dan Implikasinya di Indonesia, Jurnal Ilmu Hukum, Vol. 9, No. 1.

[3] Adonia I. Laturette. Kewenangan Pemerintah Daerah Terhadap Tanah ulayat. Jurnal Sasi Vol. 17 No.3 Juli-September 2011.

[4] Andreas, R., Adi, L. K., \& Sulastuti, S. (2019). The Effect of Colonialism on Implementation of Agrarian Reform in Indonesia. Fiat Justisia: Jurnal Ilmu Hukum, 13 (2).

[5] Arie S. Hutagalung dalam Haris, A. 2005, Pengaruh Penatagunaan Tanah terhadap Keberhasilan Pembangunan Infrastruktur dan Ekonomi, Perencanaan Pembangunan.

[6] Bangsawan, M., \& Absori, S. H. (2019). Kebijakan sertifikasi tanah dan implikasinya terhadap kesejahteraan masyarakat (Doctoral dissertation, Universitas Muhammadiyah Surakarta).

[7] Bangsawan, M. I. (2017). Pemberdayaan Ekonomi Kreatif di Kota Surakarta Melalui Instrumen Hukum Perizinan Industri Kreatif. Perizinan di Era Citizen Friendly.

[8] Husen, A. (2011). Dinamika Hukum Dalam Pengakuan dan Perlindungan Hak Masyarakat Hukum Adat Atas Tanah. Yogyakarta: LaksBang Pressindo.

[9] Ismail, I. (2010). Kedudukan dan Pengakuan Hak Ulayat Dalam Sistem Hukum Agraria Nasional. Kanun Jurnal Ilmu Hukum, 12 (1). 
[10] Ismi, H. (2012). Pengakuan dan perlindungan hukum hak masyarakat adat atas tanah ulayat dalam upaya pembaharuan hukum nasional. Jurnal Ilmu Hukum, 3 (1).

[11] Kodir, A., \& Mushoffa, I. (2017). Islam, Agrarian Struggle, and Natural Resources: The Exertion of Front Nahdliyin for Sovereignty of Natural Resources Struggle Towards Socio-Ecological Crisis in Indonesia. KARSA: Journal of Social and Islamic Culture, 25 (1).

[12] Manoe, S. B. (2014). Konstruksi Hak Menguasai Negara Dalam Tata Laksana Pengadaan Tanah Bagi Kepentingan Umum Di Kabupaten Semarang. Jurnal Pembaharuan Hukum, 1(2).

[13] Nurhayati, N., \& Bangsawan, M. I. (2019). The Sustainable Development Licensing Policy Of Creative Industry In The Era Of Asean Economic Community (AEC) In Surakarta, Indonesia. Humanities \& Social Sciences Reviews, 7 (3), 25-31.

[14] Markus, D. P., \& Purnawan, A. (2017). Analisis Yuridis Kedudukan Hukum Adat dan Peranan Notaris-ppat dalam Proses Pendaftaran Tanah Menurut Undang-undang Pokok Agraria di Kota Sorong Papua Barat.Jurnal Akta, 4(3).

[15] Mujiburohman, D.A., (2018), Potensi Permasalahan Pendaftaran Tanah Sistematik Lengkap (PTSL), BHUMI: Jurnal Agraria dan Pertanahan, 4(1).

[16] Muljono, B. E. (2016). Pendaftaran Tanah Pertama Kali Secara Sporadik Melalui Pengakuan Hak. Jurnal Independent, 4(1).

[17] Nurjaya, I. N. (2011). Adat Community Lands Right as Defined within the State Agrarian Law of Indonesia: Is It a Genuine or Pseudo-Legal Recognition. US-China Law Review, 8.

[18] Pratiwi, S. I. (2015). Penyelesaian Sengketa Tanah Ulayat Antara Masyarakat Hukum Adat Dengan Taman Nasional Tessonilo. Kumpulan Jurnal Mahasiswa Fakultas Hukum.

[19] Razuni, G., \& Pramanti, A. (2020). No Agrarian Reform: Revolutie Without Revolution? Jurnal Partisipatoris, 2 (1).

[20] Sabardi, L. (2014). Konstruksi Makna Yuridis Masyarakat Hukum Adat dalam Pasal 18B UUDN RI Tahun 1945 untuk Identifikasi Adanya Masyarakat Hukum Adat. Jurnal Hukum \& Pembangunan, 44 (2).

[21] Santosa, S., Wicaksono, A., \& Nugroho, R. (2019). Multi-Role Collaboration of Ministries and Institutions in the Implementation of Agrarian Reform in Indonesia. BHUMI: Jurnal Agraria dan Pertanahan, 5 (3).

[22] Setyani, A. N., \& Suwondo, D. (2020). Tinjauan Yuridis Peralihan Hak Atas Tanah Karena Jual Beli Di Kabupaten Demak. Prosiding Konferensi Ilmiah Mahasiswa Unissula (KIMU) Klaster Hukum.

[23] Simarmata, R. (2015). Kedudukan Hukum dan Peluang Pengakuan Surat Keterangan Tanah Adat. Kemitraan bagi Pembaruan Tata Pemerintahan.

[24] Suwondo, D., \& Saputra, I. (2019). Peran Dan Tanggung Jawab Pejabat Pembuat Akta Tanah Dalam Pelaksanaan Kegiatan Pendaftaran Tanah. Jurnal Hukum, 35(2).

[25] Widodo, S. (2017). A Critical Review of Indonesia's Agrarian Reform Policy. Journal of Regional and City Planning, 28 (3). 
[26] Windari, R. A. (2014). Keberpihakan Regulasi Pertanahan terhadap Hak Masyarakat Adat (Studi Kasus Sengketa Tanah Adat di Desa Kubutambahan, Kecamatan Kubutambahan, Kabupaten Buleleng). Jurnal Ilmu Sosial dan Humaniora, 3(1).

[27] Yarsina, N. (2018). Perlindungan Hukum Terhadap Tanah Ulayat Yang Telah Bersertifikat Di Kota Bukittinggi. JCH (Jurnal Cendekia Hukum), 3 (2).

\section{Book}

[1] Hefner, R. W. (2011). Civil islam: Muslims and democratization in indonesia (Vol. 40). Princeton University Press.

[2] Rombot, D. A. E. (2015). Pendaftaran tanah adat dan pembangunan masyarakat Minahasa di Indonesia (Doctoral dissertation, Universiti Sains Malaysia).

[3] Santoso Urip. (2012). Hukum Agraria Kajian Komprehensif, Jakarta: Kencana Prenada Media Group.

[4] Sembiring Julius, (2016), Tanah Negara, Jakarta: Prenadamedia Group.

\section{Internet}

[1] Prasetyo, F. (2019). The struggle for land rights: Indonesian (Urban) Agrarian Reform and (Against) the Global Land Forum in Bandung. https://platypus1917.org/2019/07/02/the-struggle-for-landrights/. 